\title{
OSMOMETRIC BEHAVIOR OF NORMAL HUMAN ERYTHROCYTES
}

\author{
By GEORGE M. GUEST ANd MARY IVING \\ (From The Children's Hospital Research Foundation and the Department of Pediatrics, College \\ of Medicine, University of Cincinnati, Cincinnati)
}

(Received for publication October 22, 19+1)

It is generally accepted that when erythrocytes are suspended in hypotonic solutions they first take up water and swell, and then at some critical tonicity burst and allow hemoglobin to escape. While there are many indications that the permeability of these cells to both salts and water may vary considerably in different conditions $(1,2,3)$, quantitative data on the osmometric behavior of either normal or abnormal erythrocytes are scarce. Methods used in clinical studies of the osmotic fragility of erythrocytes are mostly limited to qualitative observations of hemolysis as an indication of the rupture of the cells.

Quantitative methods for estimating the amounts of hemoglobin liberated from erythrocytes in salt solutions of different tonicities were devised in 1903 by Arrhenius and Madsen (4) and in 1921 by Hastings (5), each making use of visual colorimetry; and recently Waugh and Asherman (6) and Hunter (7) used photoelectric colorimetry for the same purpose. Such methods permit the estimation of the number of cells ruptured at each step of a hemolytic series but tell nothing of the osmotic behavior of the cells during stages of their swelling up to the point of rupture. In 1939 we developed a method (8) for measurement of changes in volume of erythrocytes in hypotonic salt solutions, but this method did not account for the swelling of cells remaining intact after hemolysis of part of the cells at critical tonicities. That method has since been elaborated, as here described, to include quantitative measurements of hemolysis as well as the volume of the red cells at each tonicity in a series. These parallel determinations permit the calculation of the swelling of intact cells both before hemolysis begins and in solutions where partial hemolysis has occurred. Data obtained by this method in studies of normal human erythrocytes are reported here. Data on abnormal types of human erythrocytes and erythrocytes of a number of other species will be reported later.

\section{METHOD}

Apparatus. The modified Van Allen hematocrit tube illustrated in Figure 1 contains $8.0 \mathrm{cc}$. when filled to the upper mark, and the graduated portion of the stem (100 divisions, numbered by tens) contains $0.02 \mathrm{cc}$. It is necessary that the bulb of the pipette should slope steeply and smoothly into the stem so that no cells will stick at the shoulder during centrifugation. For centrifugation of a series of the pipettes, we use the International Centrifuge Type SB, No. 2, with 8-place head and 3-place trunnion carriers. The pipettes, each sealed with a spring clip as shown in Figure 1, are placed in 15 cc. centrifuge tube holders. The Evelyn photoelectric colorimeter (9) is used with the light filter 540 for measurement of hemoglobin concentrations.

Solutions. Salt solutions of different concentrations varying from 0.9 to 0.1 per cent sodium chloride are prepared and kept as described previously (8).

Blood samples. Either defibrinated or heparinized blood may be used. As stated in the earlier paper (8), best results are obtained if the volume of cells is above 30 per cent.

Procedure. Fit a rubber suction tube with mouthpiece to the upper end of the pipette and draw blood into the stem to the 100 mark. After wiping excess blood from the tip draw the blood into the bulb and, after it, the appropriate salt solution to fill the bulb almost to the 8.0 cc. mark. By not filling the pipette quite to the mark at this stage, an air bubble is left in the bulb to facilitate mixing. Mix by inverting the pipette repeatedly, with a finger placed over the upper end. Make the dilution of blood in 0.9 per cent $\mathrm{NaCl}$ solution in duplicate. Fill thus an appropriate number of pipettes (usually a series of 12) with solutions of $\mathrm{NaCl}$ decreasing in concentration to that which gives complete hemolysis as judged by the eye. Choice of decrements in concentrations may be made to suit the needs of individual experiments, the smaller decrements of 0.025 per cent being used in the range where hemolysis is expected to occur. In the same manner, dilute the blood with distilled water in the last pipette of the series. Keep the filled pipettes in a horizontal position for one hour. Since the cells settle and may adhere to the glass, resuspend them at the end of the hour by repeatedly inverting the pipettes as before.

Centrifuge the pipettes 20 minutes at 2500 to 3000 r.p.m., and read the height of the column of packed red cells in per cent (see Table I). Add distilled water through the top of each pipette to bring the fluid to the $8.0 \mathrm{cc}$. mark. Then withdraw the fluid from each bulb by means of a long thin-stemmed pipette and transfer it to a colorimeter tube. To insure absence of turbidity, add 


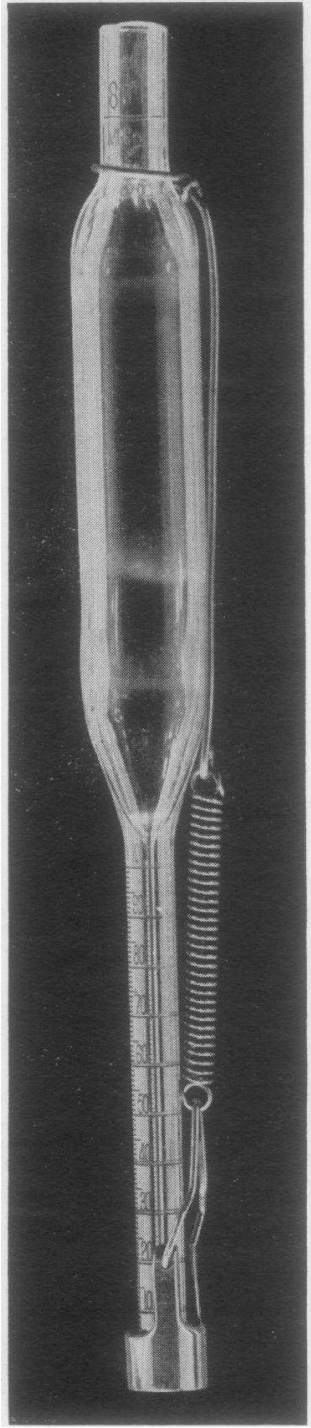

Fig. 1. Blood Diluting Pipette, a Modified Van Allen Hematocrit Tube (14)

Made by Macalaster Bicknell Company, 243 Broadway, Cambridge, Mass.

a drop of concentrated ammonium hydroxide to each, a few minutes before the colorimetric readings are to be made. Read the light transmissions in the Evelyn instrument, with the filter 540 . Use the fluid from the first pipette of the series ( 0.9 per cent $\mathrm{NaCl})$ as the blank for adjustment of the galvanometer. Light transmission of this fluid is usually slightly less than that of distilled water, presumably owing to substances in the blood plasma.

To determine the total hemoglobin content of the blood dilute a portion 1:400 in distilled water, and transfer this "total" hemolysate, uncentrifuged, to a colorimeter tube.
Shortly before reading its limit transmission, add to it a drop of concentrated ammonium hydroxide to insure both complete hemolysis and absence of turbidity.

For calculating the per cent hemolysis in each fluid of the series, all the galvanometer readings may be converted to hemoglobin values by means of a previously established factor or calibration curve, and these in turn converted to percentages of the total hemoglobin; or more directly, the density or $L$ value $(L=2-\log \mathrm{G})$ of each fluid may be divided by that of the total hemolysate to obtain the per cent hemolysis. ${ }^{1}$

Divide the readings of the height of the column of cells in the stem of each pipette by that of the first tube, and multiply by 100 to express the cell volumes in percentages of the initial volume of the cells in 0.9 per cent $\mathrm{NaCl}$ solution. $^{2}$ Where partial hemolysis has occurred, calculate the volume of the intact cells by correcting the observed volumes for the loss of cells by hemolysis. Table I illustrates the tabulation of data thus obtained on the erythrocytes of a normal infant. For example, in 0.425 per cent $\mathrm{NaCl}$ solution the cells in the stem of the pipette occupied a volume (reading 55.6) equal to 142 per cent of the volume of cells in the first pipette; but these intact cells were only 81.6 per cent $(100-18.4$ per cent hemolysis $)$ of the original number. Therefore, $142 \div 81.6 \times 100=$ $174=$ the corrected volume of the intact cells in per cent of their initial volume.

1 In some instances the advisability of using the hemoglobin content of the centrifuged water hemolysate (the last tube of the series), as representing complete hemolysis, might be considered. With normal bloods the difference between this and the total hemoglobin is small, but the difference varies greatly with different types of blood, and is greatest with the erythrocytes of sicklemia; in some cases the centrifuged water hemolysate may contain only 90 per cent or less of the total hemoglobin. Ponder has called the hemoglobin thus centrifuged out "residual hemoglobin" and finds that it is adsorbed on the ghosts (personal communication).

2 For the studies described later under RESUlts, the volume of cells in each sample of heparinized blood was determined by centrifugation of the undiluted blood in capillary tubes at about 12,000 r.p.m. for 5 minutes (10). The cell volume thus determined was usually from 0.5 to 2 volumes per 100 volumes of blood lower than the volume read in the first Van Allen tube; such a difference might be due to a difference in packing of the cells at different speeds (although longer spinning in the Van Allen tubes did not pack the cells further) or to a slightly higher real volume of the cells in the 0.9 per cent $\mathrm{NaCl}$ solution. As a basis for comparison of different bloods, it was deemed preferable to calculate the volumes of the cells in the series of hypotonic solutions in percentages of their volume in 0.9 per cent $\mathrm{NaCl}$ solution (the first tube) rather than in the undiluted blood. For some purposes, however, it may be better to use the cell volume determined in the undiluted blood as the initial value. 
TABLE I

Hemolysis and changes in volume of normal erythrocytes diluted 1: 400 with solutions of sodium chloride

Initial mean dimensions of these cells are listed as the first example of normal infant's blood in Table II, and the changes are shown graphically, for comparison with expected swelling of the cells, in Figure 2.

\begin{tabular}{|c|c|c|c|c|}
\hline \multirow{2}{*}{$\mathrm{NaCl}$} & \multirow{2}{*}{$\begin{array}{c}\text { Hemo- } \\
\text { lysis }\end{array}$} & \multicolumn{3}{|c|}{ Volume of cells } \\
\hline & & $\begin{array}{c}\text { Read- } \\
\text { ings }\end{array}$ & $\begin{array}{l}\text { Uncorrected } \\
\text { for hemolysis }\end{array}$ & $\begin{array}{l}\text { Corrected } \\
\text { for hemolysis }\end{array}$ \\
\hline $\begin{array}{l}\text { per } \\
\text { cent }\end{array}$ & $\begin{array}{l}\text { per } \\
\text { cent }\end{array}$ & $\begin{array}{l}\text { per } \\
\text { cent }\end{array}$ & $\begin{array}{l}\text { per cent of volume } \\
\text { in first tube }\end{array}$ & $\begin{array}{l}\text { per cent of solume } \\
\text { in first tube }\end{array}$ \\
\hline 0.900 & 0 & 39.2 & 100 & \\
\hline 0.800 & 0 & 42.5 & 108 & \\
\hline 0.700 & 0 & 47.2 & 120 & \\
\hline $\begin{array}{l}0.600 \\
0.550\end{array}$ & $\begin{array}{l}0 \\
0\end{array}$ & $\begin{array}{l}51.4 \\
55.4\end{array}$ & 131 & \\
\hline 0.525 & 0 & 58.6 & 149 & \\
\hline 0.500 & 0.6 & 60.4 & 154 & 155 \\
\hline 0.475 & 4.0 & 62.4 & 159 & 166 \\
\hline $\begin{array}{l}0.450 \\
0.425\end{array}$ & 9.3 & 61.0 & 156 & 172 \\
\hline $\begin{array}{l}0.425 \\
0.400\end{array}$ & $\begin{array}{l}18.4 \\
45.8\end{array}$ & $\begin{array}{l}55.6 \\
35.0\end{array}$ & $\begin{array}{r}142 \\
89\end{array}$ & $\begin{array}{l}174 \\
165\end{array}$ \\
\hline 0.375 & 65.6 & 19.4 & 50 & 144 \\
\hline 0.350 & 80.5 & $7.6 ?$ & $19 ?$ & 99? \\
\hline $\begin{array}{c}0.325 \\
\mathrm{H}_{2} \mathrm{O}\end{array}$ & $\begin{array}{l}91.5 \\
97.9\end{array}$ & $?$ & $0 ?$ & \\
\hline & & & & \\
\hline
\end{tabular}

\section{APPLICATIONS OF THE METHOD AND RESULTS}

In applying the method to studies of the osmometric behavior of erythrocytes, further measurements and calculations were made following a plan of study suggested in recent papers by Haden $(11,12)$ and Ponder $(2,3)$.

The red cells in each sample of heparinized blood were counted with a hemocytometer as usual, their volume in the undiluted blood was determined by the method of Guest and Siler (10), and their mean volume was calculated in the usual manner by dividing the volume of the cells by their number per c.mm. of blood. The mean diameter of the cells was read from stained films by means of the Haden-Hauser erythrocytometer (13) with a drop of 0.9 per cent $\mathrm{NaCl}$ solution and cover glass placed over the blood film. From values for the mean volume and mean diameter, the mean thickness of the cells was calculated by the formula $T=V / \pi r^{2}$. Their mean surface area was calculated as that of a flat disc of the given thickness and diameter, and the volume of a sphere with this surface area was calculated. The per cent swelling which the cells would undergo to become spheres with the same mean surface area was then obtained from the ratio of their initial mean volume to that of the spheres to which they might be converted without exceeding this surface area (i.e., without rupture of the cell membranes). The latter value was designated "expected maximal volume."

The "expected osmometric volume" of the cells at each tonicity (i.e., the volume they should attain if they behaved as perfect osmometers) was calculated according to Ponder's formula: $V=$ $W(1 / T-1)+100$; where $V=$ the new volume of the cells in per cent of their initial volume; $W=$ the percentage by volume of water in the cells, taken as 70 per cent $;^{3} T=$ the ratio of the tonicity of the medium to 0.9 per cent $\mathrm{NaCl}$ solution (i.e., with 0.45 per cent $\mathrm{NaCl}, T=0.5$ ); $100=$ the initial volume of the cells.

Figure 2 illustrates the swelling and hemolysis of the erythrocytes of a normal infant (data in Table I). The swelling (curves 2 and 3 ) closely

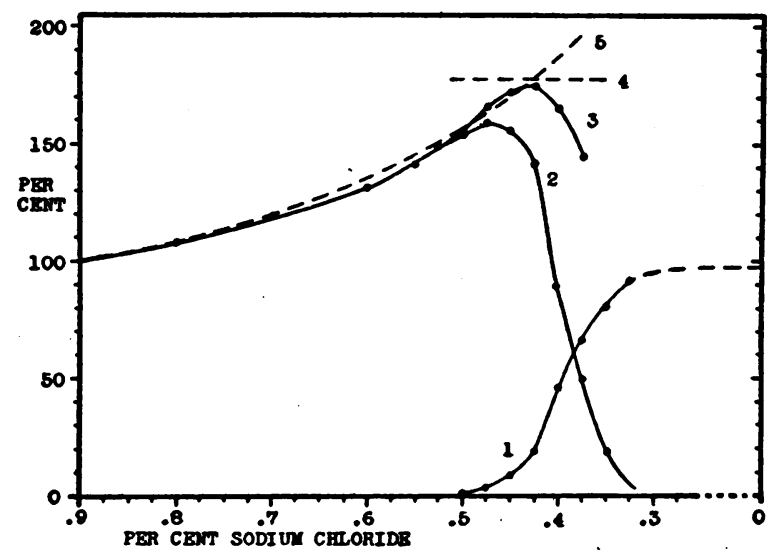

Fig. 2. The Blood of a Normal Infant, J. P., 14 months of age; Hemolysis and Changes in Volume of Erythrocytes in Hypotonic Salt Solutions (data LISTED IN TABLE I)

Hemolysis is expressed in per cent of the total hemoglobin in the sample. Cell volumes are expressed in per cent of the initial volume of the cells in 0.9 per cent $\mathrm{NaCl}$ solution. The symbols represent, respectively: 1 . Hemolysis; 2 . Observed cell volume; 3 . Cell volumes corrected for hemolysis, i.e., the volume of the unhemolyzed cells; 4. Expected maximal mean cell volume calculated from the mean surface area according to Haden; 5. Expected osmometric volume of the cells at different tonicities, calculated according to Ponder, assuming the initial water content of the cells to be 70 per cent.

${ }^{8}$ In different papers on this subject Ponder used the figures 67 per cent (2) and 60 per cent (3) for the water content of rabbit erythrocytes. Our own data on the water content of human erythrocytes, determined by drying at $105^{\circ}$, average around 70 per cent. 
TABLE II

The swelling, axpected and found, of normal human erythrocytes in hypotonic salt solutions

\begin{tabular}{|c|c|c|c|c|c|c|c|c|c|}
\hline \multirow[b]{2}{*}{ Subjects } & \multicolumn{4}{|c|}{ Initial mean dimensions } & \multirow{2}{*}{$\begin{array}{l}\text { Volume of } \\
\text { a sphere } \\
\text { with same } \\
\text { surface } \\
\text { area }\end{array}$} & \multirow{2}{*}{$\begin{array}{l}\text { Tonicity } \\
\text { at which } \\
\text { maximal } \\
\text { owelling } \\
\text { occurred }\end{array}$} & \multirow{2}{*}{$\begin{array}{c}\text { Expected } \\
\text { osmometric } \\
\text { volume } \\
\text { at this } \\
\text { tonicity } \\
\Delta\end{array}$} & \multicolumn{2}{|c|}{ Maximum cell volume } \\
\hline & $\begin{array}{l}\text { Vol- } \\
\text { ume }\end{array}$ & $\begin{array}{c}\text { Dia- } \\
\text { meter }\end{array}$ & $\begin{array}{c}\text { Thick- } \\
\text { ness }\end{array}$ & $\begin{array}{c}\text { Surface } \\
\text { area }\end{array}$ & & & & $\begin{array}{l}\text { Expected, } \\
\text { calculated } \\
\text { from sur- } \\
\text { face area }\end{array}$ & $\begin{array}{l}\text { Found. } \\
\text { observed } \\
\text { volume cor- } \\
\text { rected for } \\
\text { hemolysis }\end{array}$ \\
\hline & $\mu^{3}$ & $\mu$ & $\mu$ & $\mu^{2}$ & $\mu^{3}$ & $\begin{array}{l}\text { per cent } \\
\mathrm{NaCl}\end{array}$ & per cent & *per cent & * per cent \\
\hline Normal adults & $\begin{array}{l}90 \\
92 \\
88 \\
86 \\
91 \\
87 \\
94\end{array}$ & $\begin{array}{l}7.7 \\
7.7 \\
7.7 \\
7.6 \\
7.7 \\
7.6 \\
7.8\end{array}$ & $\begin{array}{l}1.93 \\
1.98 \\
1.89 \\
1.94 \\
1.95 \\
1.92 \\
1.97\end{array}$ & $\begin{array}{l}140 \\
141 \\
139 \\
137 \\
140 \\
137 \\
144\end{array}$ & $\begin{array}{l}156 \\
157 \\
154 \\
151 \\
156 \\
151 \\
162\end{array}$ & $\begin{array}{l}0.425 \\
0.450 \\
0.425 \\
0.450 \\
0.425 \\
0.425 \\
0.425\end{array}$ & $\begin{array}{l}179 \\
170 \\
179 \\
170 \\
179 \\
179 \\
179\end{array}$ & $\begin{array}{l}173 \\
171 \\
175 \\
176 \\
172 \\
174 \\
172\end{array}$ & $\begin{array}{l}179 \\
172 \\
175 \\
178 \\
180 \\
172 \\
175\end{array}$ \\
\hline Normal infants and children & $\begin{array}{l}82 \\
77 \\
77 \\
84 \\
82\end{array}$ & $\begin{array}{l}7.6 \\
7.4 \\
7.4 \\
7.5 \\
7.5\end{array}$ & $\begin{array}{l}1.81 \\
1.79 \\
1.79 \\
1.90 \\
1.86\end{array}$ & $\begin{array}{l}134 \\
128 \\
128 \\
133 \\
132\end{array}$ & $\begin{array}{l}146 \\
136 \\
136 \\
144 \\
143\end{array}$ & $\begin{array}{l}0.425 \\
0.425 \\
0.425 \\
0.425 \\
0.425\end{array}$ & $\begin{array}{l}179 \\
179 \\
179 \\
179 \\
179\end{array}$ & $\begin{array}{l}178 \\
177 \\
177 \\
174 \\
174\end{array}$ & $\begin{array}{l}174 \\
174 \\
172 \\
173 \\
173\end{array}$ \\
\hline Normal newly born infants & $\begin{array}{l}110 \\
108 \\
109\end{array}$ & $\begin{array}{l}8.1 \\
7.7 \\
7.7\end{array}$ & $\begin{array}{l}2.14 \\
2.32 \\
2.34\end{array}$ & $\begin{array}{l}157 \\
149 \\
150\end{array}$ & $\begin{array}{l}185 \\
171 \\
173\end{array}$ & $\begin{array}{l}0.450 \\
0.450 \\
0.475\end{array}$ & $\begin{array}{l}170 \\
170 \\
162\end{array}$ & $\begin{array}{l}168 \\
158 \\
159\end{array}$ & $\begin{array}{l}165 \\
155 \\
153\end{array}$ \\
\hline
\end{tabular}

Volume of a perfect osmometer, in per cent of its initial volume, assuming the initial water content to be 70 per cent by volume.

* Values in per cent of the initial volume of the cells determined in 0.9 per cent $\mathrm{NaCl}$ solution.

approached at all points that expected in a perfect osmometer (curve 5), and the maximum swelling at the peak closely approached that predicted from the surface area (broken line 4).

In Table II are listed data on several samples of erythrocytes of normal adults, children, and infants. They are arranged for comparison of the maximal volumes found in each case with the respective "osmometric" volumes expected at the tonicity where maximal swelling was found, and the expected maximal volumes calculated from the initial mean dimensions cited. The maximal volumes attained by the erythrocytes of normal subjects were about 175 per cent of the respective initial volumes, and among these there was little variation from this figure. In most instances the maximal swelling was attained in 0.425 per cent $\mathrm{NaCl}$ solution, and it was rarely found outside the range from 0.475 to 0.400 per cent $\mathrm{NaCl}$. The few observations made on the erythrocytes of newly born infants (large cells) indicated that the osmotic behavior of these cells was approximately like that of the normal erythrocytes of older individuals, although the maximal swelling of these cells was somewhat less, percentum, than that of the smaller erythrocytes of adults.

Effects of varying dilutions and of washing the cells. The maximal swelling and beginning hemolysis of erythrocytes diluted with hypotonic salt solutions in the $8.0 \mathrm{cc}$. pipettes were found to occur at tonicities of salt solution slightly higher (about 0.025 per cent of $\mathrm{NaCl}$ ) than in the original Van Allen pipettes with smaller bulbs, used as described in our earlier paper (8). The dilution of blood is approximately $1: 100$ in the original type of pipette, and 1:400 in the $8.0 \mathrm{cc}$. pipette. The maximum swelling of the cells was, however, the same at both dilutions.

When normal erythrocytes were washed by centrifugation in 0.9 per cent $\mathrm{NaCl}$ solution, resuspended in the salt solution (to give about 30 per cent volume of cells), and then tested as here described, the washed cells tended both to swell and to be hemolyzed at a slightly higher tonicity than the unwashed cells; but the maximum volume attained by the washed and unwashed cells was the same. Further studies of the effects of washing normal and abnormal types of erythrocytes 
with salt solutions of different tonicities have been made and will be reported later.

\section{DISCUSSION}

The foregoing observations on normal human erythrocytes support the general validity of two principles which have been formulated regarding the swelling of these cells in hypotonic salt solutions. The thesis of Ponder and others, that erythrocytes behave within certain limits as perfect osmometers, is supported by the close agreement found between values for "expected osmometric swelling" and for the cell volumes determined at each tonicity. The thesis of Haden and others that the maximum swelling of erythrocytes is limited by an inelastic surface membrane is supported by the close agreement found between values for the maximum swelling expected, i.e., calculated from the mean surface area of the cells, and the maximum cell volumes determined in each of the examples cited here. Similar studies of other types of erythrocytes have, however, yielded results indicating that the osmotic behavior of certain abnormal red cells does not conform to these principles. Data on abnormal human erythrocytes will be reported in a later paper.

The shapes of the curves 2 and 3 in Figure 2, representing changes in volume of the cells after the point of beginning hemolysis, lead to speculation on the way in which cells of any given sample may differ amongst themselves in their osmotic behavior. Since the observed swelling, up to the point of beginning hemolysis, corresponds closely to that expected in a perfect osmometer, it would appear that all the cells in normal bloods swell proportionately alike in all solutions of the series up to this point. There exists a possibility, however, that the observed swelling merely represents the mean, and that at different tonicities some cells swell more and some less than the average cells in the whole sample. The fact that the curve 3 falls off in the stages following about 50 per cent hemolysis suggests that the cells remaining unhemolyzed at this point either did not swell to the same degree as the others or that they became smaller after attaining a maximal volume.

Several explanations may be offered to account for the apparent dissimilarities in osmotic be- havior thus observed among the cells of one sample. Due to different physical or chemical characteristics, the more resistant cells (i.e., those hemolyzed at lower tonicities) might not follow the osmotic law and their swelling might therefore lag behind that of the cells which hemolyze first. The dimensions of the unhemolyzed cells might not correspond to the recorded mean measurements, in which case their expected maximal swelling would differ from that predicted from the mean measurements of all cells in the sample. There is a possible fallacy in the assumption that 10 per cent hemolysis, measured by the amount of hemoglobin in the supernatant fluid, represents the rupture of 10 per cent of the initial number of cells in the sample; this amount of hemoglobin would not represent the same proportion of cells if it were derived all from small cells or all from big cells. While it is generally believed that the hemolysis of individual erythrocytes is "all or none" at the point of rupture, it is conceivable that the more resistant cells may lose part of their contents without the rupture needed to liberate hemoglobin; thus the salts might escape from some cells more easily than from others, leading to less swelling if this occurred before the peak, or to shrinkage if it occurred when they were swollen to the maximum. Such considerations assume greater importance with regard to erythrocytes found in diseases characterized by abnormal red cell fragility.

To see whether differences in certain characteristics of the more resistant cells could be demonstrated, the following experiments were made. Samples of blood drawn from normal persons were diluted in centrifuge tubes with hypotonic salt solutions of tonicities chosen to produce from 25 to 72 per cent hemolysis. After standing an hour the tubes were centrifuged, the supernatant fluid was drawn off (its hemoglobin content was determined to measure the extent of hemolysis), and the cells were resuspended in a small volume of physiological salt solution. Determinations of cell count, cell volume, and hemoglobin content of this preparation were made and values calculated therefrom for the mean volume, mean hemoglobin concentration, and mean hemoglobin content of the unhemolyzed (more resistant) cells. These values did not differ notably from the mean values 
determined on all the cells of the original samples. While it thus appeared that the resistant cells did not differ materially in these characteristics from the less resistant ones, subsequent tests of these cells showed a slightly different behavior with regard to swelling and hemolysis when resuspended in the series of hypotonic solutions. Further studies of the effects of washing cells with hypotonic saline will be reported in later communications.

\section{SUMMARY}

Parallel measurements of the swelling and hemolysis of erythrocytes suspended in hypotonic salt solutions were made by means of a modified Van Allen hematocrit tube with a bulb calibrated to contain $8.0 \mathrm{cc}$. of fluid.

The swelling of normal human erythrocytes thus measured followed closely that expected if they behave as perfect osmometers.

The maximum volumes attained by normal human erythrocytes agreed closely with predictions based on their mean surface area calculated from their initial mean volume, diameter, and thickness, thus supporting the view that the erythrocyte cannot distend beyond the limit set by its surface area.

\section{BIBLIOGRAPHY}

1. Davson, H., Loss of potassium from the erythrocyte in hypotonic saline. J. Cell. and Comp. Physiol., 1937, 10, 247.

2. Ponder, E., Mammalian red cell and the properties of haemolytic systems. Protoplasma-Monographien, 1934, 6, 117.
3. Ponder, E., Red cell as an osmometer. Cold Spring Harbor Symp., Quant. Biol., 1939, 8, 133.

4. Arrhenius, S., and Madsen, T., Anwendung der physikalischen Chemie auf das Studium der Toxine und Antitoxine. Ztschr. f. physik. Chemie, 1903, 44, 7. (Quoted by Harvey, W. F., Studies in method and standardization of blood examination; estimation of erythrocyte fragility and normal standard. Edinburgh M. J., 1937, 44, 100.)

5. Hastings, A. B., Physiology of fatigue; physicochemical manifestations of fatigue in the blood. U. S. Public Health Bull. No. 117, Government Printing Office, Washington, 1921.

6. Waugh, T. R., and Asherman, E. G., Use of index of hemolysis in expressing fragility of erythrocytes. J. Lab. and Clin. Med., 1938, 23, 746.

7. Hunter, F. T., Photoelectric method for quantitative determination of erythrocyte fragility. J. Clin. Invest., 1940, 19, 691.

8. Guest, G. M., and Wing, M., Method for determination of erythrocyte fragility, using Van Allen hematocrit tubes for measurement of changes in volume of cells in hypotonic salt solutions. J. Lab. and Clin. Med., 1939, 24, 850.

9. Evelyn, K. A., Stabilized photoelectric colorimeter with light filters. J. Biol, Chem., 1936, 115, 63.

10. Guest, G. M., and Siler, V. E., Centrifuge method for determination of volume of cells in blood. J. Lab. and Clin. Med., 1934, 19, 757.

11. Haden, R. L., Nature of hemolytic anemia. Univ. Wisconsin, Symposium on Blood, 1939, p. 83.

12. Haden, R. L., Studies in Hematology. University of Kansas, Extension Division, 1940.

13. Haden, R. L., New instrument for diffractometric measurement of diameter of red blood cells. J. Lab. and Clin. Med., 1940, 25, 399.

14. Van Allen, C. M., Hematocrit method. J. Lab. and Clin. Med., 1925, 10, 1027. 